\title{
ANALIZA STVARNIH I PLANIRANIH TROŠKOVA ODRŽAVANJA I UPORABE GRAĐEVINA
}

\author{
Branka Bognar \\ Sveučilište Josipa Jurja Strossmayera u Osijeku, Građevinski Fakultet Osijek, mag.ing.aedif. \\ Saša Marenjak \\ Sveučilište Josipa Jurja Strossmayera u Osijeku, Građevinski Fakultet Osijek, prof.dr.sc. \\ Hrvoje Krstić \\ Sveučilište Josipa Jurja Strossmayera u Osijeku, Građevinski Fakultet Osijek, dr.sc.
}

\begin{abstract}
Sažetak: Analiza održavanja i uporabe građevina opisuje se kao skup trajnih aktivnosti koje sadrže tehnička i pridružena im administrativna djelovanja, kako bi se tijekom cijeloga vijeka uporabe građevini u cjelini i svim njezinim dijelovima osigurala razina služnosti u dostupnim (zadovoljavajućim) granicama. Uporabom metode proračuna troškova održavanja i uporabe u ranoj fazi projektiranja moguće je racionalizirati troškove održavanja i uporabe, planirati iste buduće troškove te spriječiti ili umanjiti utjecaj prekida poslovanja zbog potreba održavanja i funkcionalne uporabivosti. Rezultati proračuna troškova održavanja i uporabe građevina znatno ovise o duljini vremenskog razdoblja za koje se radi proračun i primijenjenoj diskontnoj stopi pri svođenju troškova na neto sadašnju vrijednost. U ovom radu predstavljena je studija slučaja kojom se uspoređuju stvarni i planirani troškovi desetogodišnjeg održavanja i uporabe građevine namijenjene fakultetskoj funkciji. Definiraju se aktivnosti planiranog preventivnog održavanja, reaktivnog održavanja i zamjene istrošenih materijala, te troškovi uporabe na osnovi kojih se uspoređuju isti troškovi za razdoblja od 10 i 50 godina.
\end{abstract}

Ključne riječi: održavanje građevina, analiza troškova održavanja i uporabe, uporabni vijek građevine

\section{ANALYSIS OF THE FACILITIE'S ACTUAL AND ESTIMATED COSTS OF MAINTENANCE AND OPERATION}

\begin{abstract}
Analysis of Facility Management can be described as a set of ongoing activities which include technical and administrative activities associated with them, aiming at insurance of service life of the facility as a whole and all its parts at certain satisfactory levels and availability. Applying the Maintenance and Operation cost Analysis during the early design phase it is possible to reduce maintenance and operating costs, plan future costs of ownership and prevent or reduce the impact of business interruption due to the maintenance and functional usability. The results of the maintenance and operation cost analysis depends considerable on the period of life cycle cost analysis and applied discount rate once net present values are populated. Represented case study compares actual and planned maintenance and operation costs during the period of ten years for educational facility. Activities of periodic works and repairs, reactive maintenance activities and life cycle replacement activities for the Facility are defined and then applied as the basis for the maintenance and operation costs comparison for two periods of 10 and 50 years.
\end{abstract}

Key words: Facility management, maintenance and operation cost analysis, operational service life of a facility 


\section{Uvod}

Vlasnici nekretnine dužni su osigurati uvjete za njezino sigurno korištenje, a u slučaju kada se radi o javnoj zgradi, poslove održavanja vodi tehnička služba. Pristup gospodarenju uvjetovan je zakonom te potrebama i mogućnostima investitora i krajnjih korisnika. Suvremeni pristup u gospodarenju građevinama treba usvojiti načela važećih hrvatskih normi [1]:

- HRN ISO 15686-1:2002 Zgrade i druge građevine - Planiranje vijeka uporabe - 1. dio: Opća načela

- $\quad$ HRN ISO 15686-2:2002 Zgrade i druge građevine - Planiranje vijeka uporabe - 2. dio: Postupci predviđanja vijeka uporabe

- $\quad$ HRN ISO 15686-3:2004 Zgrade i druge građevine - Planiranje vijeka uporabe - 3. dio: Neovisne ocjene (auditi) i pregledi svojstava.

Za projekte javnih građevina karakteristično je što in isti investitor - vlasnik „Vodi“ od početka do kraja, odnosno od izbora projektne ideje, preko izrade projekta, izbora izvođača radova i realizacije do cijele faze eksploatacije i eventualnog rušenja na kraju etape uporabe. S obzirom na to, investitor ima interesa za cjeloživotnu optimizaciju troškova, odnosno njihovo planiranje prije izvedbe i kontrolu tijekom građenja (preko nadzornog inženjera) te za vrijeme uporabe (gospodarenje građevinama). Tijekom vijeka trajanja uporabe javlja se nekoliko skupina troškova, od kojih mnogi (kao i drugi troškovi uporabe) umnogome ovise o odlukama koje se donose prije početka gradnje.

Gospodarenje građevinama opisuje se kao skup trajnih aktivnosti koje sadrže tehnička i pridružena im administrativna djelovanja kako bi se tijekom cijeloga vijeka uporabe građevini u cjelini i svim njezinim dijelovima osigurala razina služnosti u dostupnim (zadovoljavajućim) granicama [2].

Održavanje podrazumijeva niz zakonom propisanih pregleda, popravaka i zamjena istrošenih dijelova (već prema njihovom vijeku trajanja i uvjetima uporabe). Iste je moguće dobro isplanirati prije nego što se moraju obaviti, a kada se realiziraju, treba in kontinuirano pratiti i evidentirati, kao i trenutačno stanje raspoloživosti građevine.

Za potrebe ovog istraživanja prikupljeni su podatci o stvarnim troškovima održavanja i uporabe građevine namijenjene fakultetskoj funkciji, za vremensko razdoblje od 1999. do 2008. godine. U tom trenutku starost građevine je bila 50 godina. Radi utvrđivanja udjela pojedinih skupina troškova u ukupnim troškovima održavanja i uporabe građevina, u ovome radu su analizirani stvarni troškovi održavanja i uporabe tijekom razdoblja od deset godina. Također je izvršeno planiranje troškova održavanja i uporabe građevine za naredno razdoblje uporabe od 50 godina, što je omogućilo analizu isplativosti daljnjih ulaganja u građevinu i troškova izgradnje nove građevine iste funkcionalne namjene.

Građevina je zatvorenog tlocrtnog oblika, sastoji se od podruma, prizemlja, I kata i potkrovlja, ukupne površine 2.374,67 m2. Izgrađena je 1959. godine za potrebe srednjoškolskog obrazovanja. Nosivi zidovi su od opeke dimenzija $38 \mathrm{~cm}$, a pregradni zidovi su $12 \mathrm{~cm}$, zidani punom opekom. Međukatna konstrukcija riješena je $A B$ pločom debljine $15 \mathrm{~cm}$. Krovište je drveno, jednostrešno i dvostrešno s pokrovom od pocinčanog lima. Stropovi i zidovi potkrovlja izvedeni su gips-kartonskim pločama. Horizontalne komunikacije odvijaju se širokim hodnicima povezanim po vertikali masovnim betonskim dvokrakim stubištem. Stanje građevine je uredno, uz napomenu da je u razdoblju od 1999.-2002. godine izvedena značajna rekonstrukcija. Tijekom obnove građevine uređeno je potkrovlje, djelomično su zamijenjene vodovodne, telefonske i električne instalacije, te kanalizacija. Cijeli objekt je u sustavu vatrodojave $s$ automatskom centralom za zaštitu od požara. Većina prostorija je klimatizirana pojedinačnim rashladnim jedinicama, izvršena je zamjena dotrajalog parketa laminatom, stolarija je obojana, a zidovi prostorija oličeni. U podrumskim prostorijama uređeni su prostori za laboratorije, što je uključilo oblaganje zidova i podova keramičkim pločicama. Analizirana građevina je pretrpjela manja oštećenja tijekom rata (1991.-1995. godine), a za potrebe fakulteta je obnovljena koncem 90-tih godina (prije rata također se koristila za srednjoškolsko i fakultetsko obrazovanje), nekoliko godina nakon rata (od 1995. do 1998. godine u istoj su bili smješteni prognanici), tako da se korištenje intenziviralo tek nakon 1999. godine. Nakon obnove građevina je postigla zadovoljavajuću razinu služnosti, a plan troškova održavanja i uporabe prikazan u ovom radu trebao bi osigurati zadržavanje postignute razine služnosti za definirano vremensko razdoblje te mogućnost analize navedenih troškova. 


\section{Održavanje građevina}

Zakon o prostornom uređenju i gradnji, članak 270 , definira obveze vlasnika građevine tijekom njezine uporabe [3]: "Vlasnik građevine dužan je osigurati održavanje građevine tako da se tijekom njezinog trajanja očuvaju bitni zahtjevi za građevinu, unapređivati ispunjavanje bitnih zahtjeva za građevinu te je održavati tako da se ne naruše svojstva građevine."

Kada se govori o održavanju građevina, potrebno je definirati dopustive granice razina složenosti i utvrditi tzv. standarde održavanja elemenata, sklopova zgrade. Standardima se određuje donja dopustiva kvaliteta koju, zbog trošenja ili starenja, trebaju imati elementi, sklopovi i zgrade, a da budu zadovoljeni svi bitni zahtjevi zgrade (stabilnost, zaštita od požara, zaštita od buke, zaštita od gubitka topline i drugi), svi bitni funkcionalni uvjeti za upotrebu (svjetlo, grijanje, hlađenje, čišćenje), te estetski uvjeti (izgled podova, zidova, stropova, kvaliteta pojedinih elemenata). Sukladno navedenom, održavanje građevina možemo podijeliti na:

- preventivno održavanje koje može biti bazirano na stanju elemenata ili na vremenu i

- reaktivno održavanje koje se bazira na otkazivanju elemenata [4].

Preventivno održavanje obuhvaća zakonom propisane periodične preglede, zamjenu istrošenih materijala i elemenata te planirane periodične radove i popravke.

Reaktivno održavanje svodi se na popravke u sklopu hitnih intervencija, kao što su kvarovi na instalacijama, sustavu grijanja, puknuća, oštećenja krovišta i slično.

Financijski pokazatelji investicijskih ulaganja razvijenih zemalja u stambeni fond pokazuju da sredstva uložena u održavanje postojećih zgrada sve više premašuju sredstva uložena u izgradnju novih zgrada. Stoga je potrebno sustavno predviđati i planirati trošenje sredstava za održavanje.

\section{1 Životni vijek građevine}

Cjelokupni životni vijek investicijskih projekata može se promatrati kroz nekoliko važnih točaka [1]:

- postizanje najpovoljnijih financijskih učinaka za investitora od ideje o potrebi investicije do uklanjanja objekta

- zadovoljenje sigurnosnih zahtjeva od faze gradnje pa sve do uklanjanja

- utjecaj građenja i same građevine na okoliš tijekom životnog vijeka

- ukupna potrošnja energije tijekom građenja i životnog vijeka

- uporabni vijek građevine koji se uspoređuje s onim definiranim u projektnoj dokumentaciji.

Koliki će biti vijek trajanja građevine ovisi o materijalima i kvaliteti izvedbe, ali i načinu održavanja i vrsti (namjeni) građevine. Treba razlikovati razdoblje na koje se računa za povrat kapitala (stvaranje profita) kod analiziranja investicija, te stvarnog životnog vijeka neke građevine. Procjena ukupnih troškova građevina (npr. analize za JPP projekte) izvodi se za ekonomski životni vijek koji, prema iskustvima u EU, za građevine visokogradnje iznosi 25 - 30 godina. Za proračun amortizacije kod utvrđivanja cijene stana, naši propisi (Uredba o načinu utvrđivanju cijene stana i garaže [5]) navode vjerojatni vijek trajanja, ovisno o vrsti osnovnih konstrukcijskih elemenata zgrade. lako su to realni rokovi, ne znači da u stvarnosti ne mogu biti nadmašeni [4].

\subsection{Uporabni vijek građevine}

Već u fazi programiranja i projektiranja građevina potrebno je utvrditi programirano trajanje buduće građevine (engl. life-cycle) kako bi se troškovi mogli optimirati s obzirom na planirano razdoblje [6]. Uporabni vijek planira se na način da se u investicijskom programu, a zatim u idejnom i glavnom projektu, definira trajnost svih elemenata zgrade, periodi njihovih popravaka, obnove ili zamjene, kako bi se zadržali na početku postavljeni zahtjevi. Planiranje treba osigurati da procijenjeni uporabni vijek zgrade ili elemenata (engl. estimated service life) bude najmanje toliko dug koliko je projektirani vijek (engl. design life). Predviđanje uporabnog vijeka treba biti uključeno u proces projektiranja zgrade da bi se "utvrdilo" kako se prikladno postižu istodobno zahtijevana svojstva, održavanje i prihvatljivi troškovi [1].

Neograničeni projektirani vijek zgrade treba rabiti vrlo rijetko, budući da isti znatno smanjuje mogućnosti projekta. Kod zgrada neograničenog vijeka uporabe za nedostupne konstrukcijske elemente također je potrebno 
planirati neograničeni vijek, dok se za npr. lako zamjenjive elemente predlaže projektirani uporabni vijek od 3-6 godina [1].

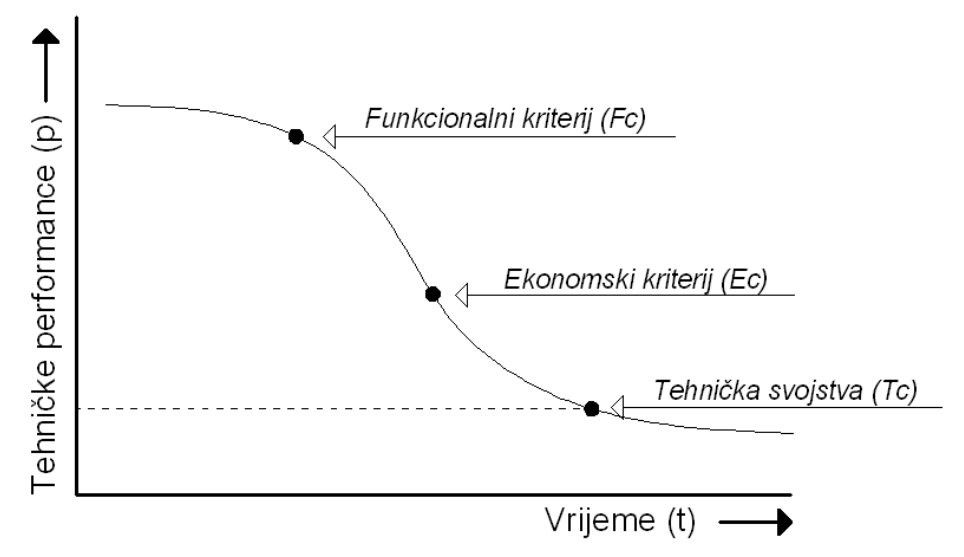

\section{Slika 1 - Različiti životni vjekovi građevina $[7,8]$}

HRN ISO 15686-1:2002 Zgrade i druge građevine - Planiranje vijeka uporabe - 1. dio: Opća načela razlikuje tri kraja uporabnog vijeka (slika 1) i to:

1. tehnički, koji je dugo vremena bio jedini uvjet za izmjenu nekog elementa, a i puno je duži od ostala dva; to je životni vijek nakon kojega proizvod gubi pretpostavljena svojstva, odnosno nakon kojega korištena i ugrađena tehnologija uzrokuje zastarjelost zgrade;

2. ekonomski, koji završava nakon što se pojavi proizvod koji zadovoljava predviđenu funkciju uz manje troškove;

3. funkcionalni, koji završava kada proizvod ne ispunjava zahtjeve korisnika ili je određena funkcija nepotrebna.

\subsection{Ukupni troškovi održavanja građevine}

Definiciju i procjenu ukupnih troškova građevine daje niz norma HRN ISO 15686 koje omogućuju usporednu procjenu troškova tijekom definiranog vremenskog trajanja građevine. Norme, definirajući trošak životnog vijeka građevine, definiraju da taj trošak obuhvaća sve životne faze od koncipiranja, definiranja, izvođenja, uporabe, do održavanja i uklanjanja građevine. Uzimaju se u obzir svi faktori koji imaju utjecaja kako na početne kapitalne troškove, tako i na buduće operativne troškove građevine.

U ne tako davno vrijeme, trošak građevine se iskazivao samo kroz kapitalne troškove stjecanja vlasništva nad zemljištem, troškove projektiranja, ishođenja dozvole za gradnju te troškova izgradnje građevine. Danas se sve više govori i o troškovima građevine koji će se pojaviti nakon puštanje građevine u uporabu. Prema podatcima istraživanja iz 2002. godine, od ukupnih investicija vezanih uz graditeljstvo u Švedskoj, 37\% odnosi se na održavanja građevina [9], dok u Velikoj Britaniji taj postotak prema podatcima iz 1995. godine iznosi 50\% [10].

Postoje dva načina na koji se mogu izračunati troškovi životnog ciklusa. Prvi način zasniva se na povijesnim podatcima o troškovima po metru kvadratnom za građevine slične vrste koji daje vrlo dvojbene rezultate zbog niza faktora (npr. uporabivost, razina održavanja i dr.), a drugi način je izrada detaljnog modela predviđanja troškova zasnovanog na predviđanju trajnosti, a time i popravaka, održavanja i izmjene konstrukcije ili dijelova konstrukcije, zajedno s troškovima energije. Ovaj drugi način omogućava optimizaciju troškova izgradnje i uporabe te analizu osjetljivosti kojom se utvrđuje koji elementi proračuna su najosjetljiviji na promjene [4]. Slika 2 prikazuje kategorije ukupnih životnih troškova građevine. 


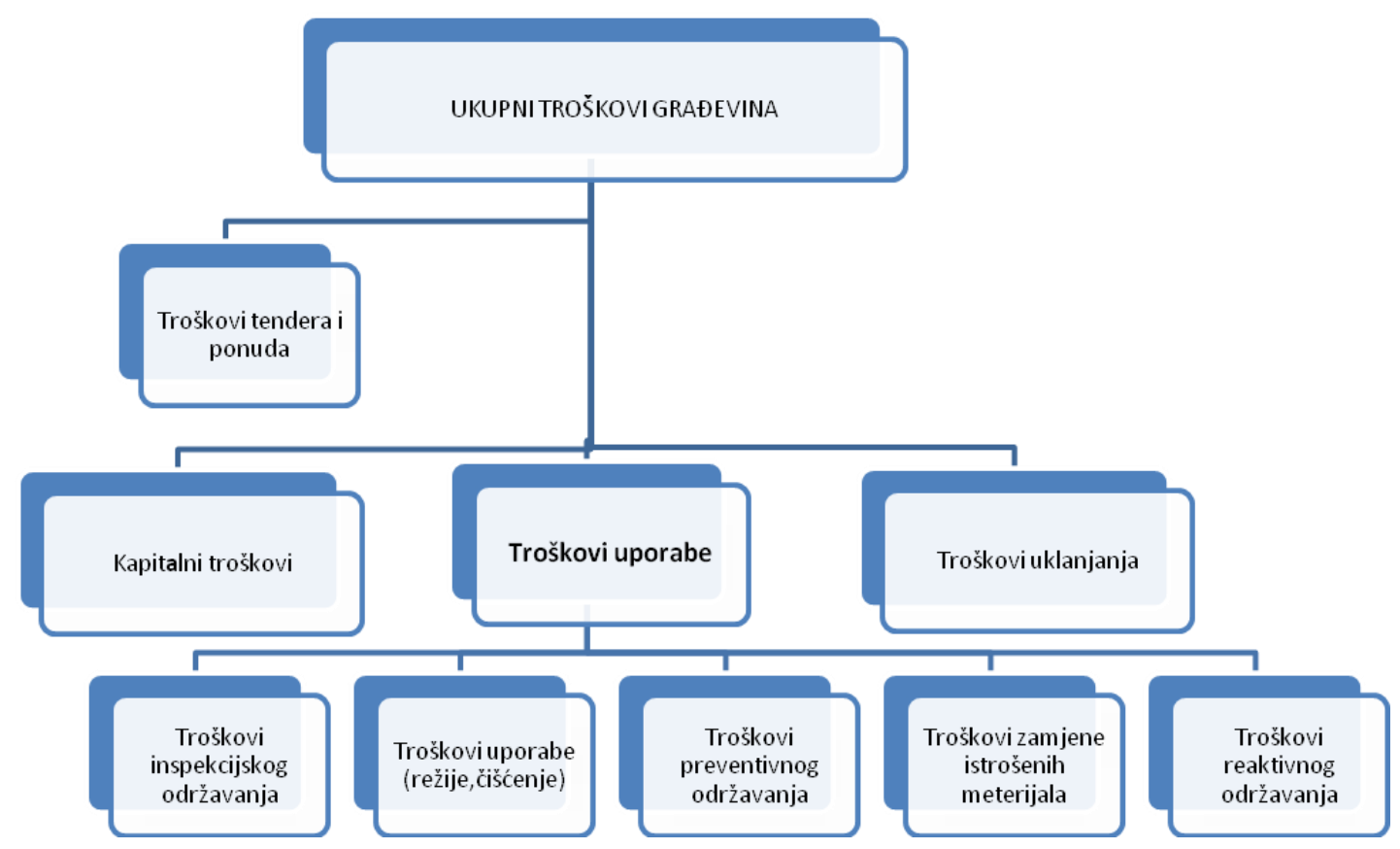

\section{Slika 2 - Kategorije ukupnih troškova [4]}

Za potrebe ovog istraživanja prikupljeni su stvarni podatci o troškovima održavanja i uporabe fakultetske građevine prema strukturi troškova prikazanoj na slici 2. Za svaku od navedenih skupina troškova održavanja i uporabe građevina popisane su sve ostvarene stavke spomenutih troškova koje su se javile tijekom promatranog vremenskog razdoblja od 10 godina. $U$ nastavku je dan popis ostvarenih aktivnosti održavanja i uporabe predmetne građevine za spomenute skupine troškova.

\subsubsection{Zakonom propisani periodični pregledi}

Zakonom propisani periodični pregledi uključuju niz aktivnosti koje su propisane važećim zakonima i propisima radi poduzimanja mjera neophodnih za sigurnost, zdravlje i život ljudi. Neki od zakonom propisanih periodičnih pregleda prikazani su u tablici 1.

Tablica 1 - Propisani periodični pregledi - primjer mogućih aktivnosti

\begin{tabular}{|c|l|c|}
\hline $\begin{array}{c}\text { redni } \\
\text { broj }\end{array}$ & \multicolumn{1}{|c|}{ opis aktivnosti } & \multicolumn{1}{|c|}{$\begin{array}{c}\text { vremenski interval } \\
\text { (godina) }\end{array}$} \\
\hline \hline 1 & Ispitivanje toplinske podstanice & 2 \\
\hline 2 & Ispitivanje gromobranske instalacije & 2 \\
\hline 3 & Ispitivanje panik-rasvjete & 4 \\
\hline 4 & Pregled i ispitivanje električnih instalacija & 1 \\
\hline 5 & Ispitivanje stabilnog sustava za dojavu požara & 1 \\
\hline 6 & $\begin{array}{l}\text { Pregled i ispitivanje funkcionalnosti stabilnog sustava za gašenje požara - } \\
\text { unutarnja hidrantska mreža }\end{array}$ & 1 \\
\hline 7 & $\begin{array}{l}\text { Pregled i ispitivanje funkcionalnosti stabilnog sustava za gašenje požara - } \\
\text { vanjska hidrantska mreža }\end{array}$ & 1 \\
\hline 8 & Ispitivanje vatrogasnih aparata & 1 \\
\hline 9 & Pregled klimatizacijskih uređaja & 1 \\
\hline
\end{tabular}




\subsubsection{Zamjena istrošenih materijala i elemenata}

Pregledom građevine definiraju se radovi na održavanju. To zahtijeva poznavanje uzroka kvara i prijedloge mjera sanacije koji trebaju odgovarati danim okolnostima, redoslijedu i učestalosti pojedinih aktivnosti na održavanju zgrada. Zastupljene su sve aktivnosti bazirane na stvarno ostvarenim izmjenama pojedinih dotrajalih materijala i elemenata građevine. Kod izrade dijela 50-godišnjeg plana i aktivnosti održavanja koji se odnosi na zamjenu istrošenih materijala i elemenata, upotrijebljeni su podatci o prosječnom vjerojatnom vijeku trajanja pojedinih materijala prema podatcima objavljenim u Narodnim novinama [1].

Neki od korištenih uporabnih vjekova elemenata ili sklopova korigirani su popravnim faktorom koji je produžio njihov uporabni vijek. Tako na primjer, dio instalacije vodovodne mreže, kanalizacije i elektroinstalacija nije mijenjan, jer je njihova kvaliteta zadovoljavajuća. Neke od mogućih aktivnosti zamjene istrošenih materijala i elemenata prikazani su u tablici 2.

Tablica 2 - Prikaz mogućih aktivnosti zamjene istrošenih materijala korištenih za izradu plana održavanja fakultetske zgrade

\begin{tabular}{|c|l|c|}
\hline $\begin{array}{c}\text { redni } \\
\text { broj }\end{array}$ & \multicolumn{1}{|c|}{ opis aktivnosti } & $\begin{array}{c}\text { vremenski interval } \\
\text { (godina) }\end{array}$ \\
\hline \hline 1 & Zamjena pokrova od pocinčanog lima & 40 \\
\hline 2 & Zamjena vanjskih prozora - drvenih & 50 \\
\hline 3 & Zamjena vanjskih vrata - drvenih & 40 \\
\hline 4 & Zamjena odvodnih vertikala i horizontala oborinske odvodnje & 15 \\
\hline 5 & Zamjena elektro instalacija & 40 \\
\hline 6 & Zamjena telefonskih instalacija,centrale & 30 \\
\hline 7 & Zamjena instalacije vodovoda i kanalizacije & 50 \\
\hline 8 & Zamjena opreme za grijanje - radijatori, podstanica & 45 \\
\hline 9 & Zamjena umivaonika, baterija & 10 \\
\hline 10 & Zamjena unutarnje stolarije, meko drvo & 40 \\
\hline 11 & Zamjena zidnih i podnih pločica & 50 \\
\hline 12 & Zamjena parketa - lamel, meko drvo & 30 \\
\hline 13 & Zamjena poda - laminat u učionicama & 20 \\
\hline 14 & Zamjena klima uređaja, instalacije & 10 \\
\hline 15 & Zamjena vatrodojave (centrala, javljači) & 15 \\
\hline
\end{tabular}

\subsubsection{Periodični radovi i popravci}

Periodični planirani radovi i popravci uključuju one aktivnosti koje se ponavljaju u relativno jednakim vremenskim intervalima. Podatci u tablici 3. izrađeni su na temelju stvarnih vremenskih intervala ponavljanja aktivnosti koje su korištene i u planu održavanja, radi lakše usporedbe troškova 10-godišnjih ostvarenih i 50-godišnjih planiranih troškova održavanja.

Tablica 3 - Prikaz ostvarenih aktivnosti periodičnih radova i popravaka korištenih za izradu plana održavanja fakultetske zgrade

\begin{tabular}{|c|l|c|}
\hline $\begin{array}{c}\text { redni } \\
\text { broj }\end{array}$ & \multicolumn{1}{|c|}{ opis aktivnosti } & $\begin{array}{c}\text { vremenski interval } \\
\text { (godina) }\end{array}$ \\
\hline \hline 1 & Bojanje zidova i stropova & 5 \\
\hline 2 & Lakiranje parketa & 10 \\
\hline 3 & Brušenje stubišta, hodnika i podesta - teraco & 20 \\
\hline 4 & Ličenje radijatora & 10 \\
\hline 5 & Ličenje opšava strehe lazurnim premazom & 5 \\
\hline 6 & Bojanje zidova hodnika uljanom bojom & 5 \\
\hline
\end{tabular}




\begin{tabular}{|c|l|c|}
\hline 7 & Ličenje metalne konstrukcije,nadstrešnice & 10 \\
\hline 8 & Ličenje vanjske stolarije & 10 \\
\hline 9 & Impregnacija površina prije završne obrade fasade & 30 \\
\hline 10 & Bojanje fasade & 30 \\
\hline 11 & Obrada dijelova fasade (sokl) & 30 \\
\hline 12 & Ličenje ograde stubišta, protupožarnih stuba, zaštitnih rešetki & 5 \\
\hline 13 & Ličenje unutarnje stolarije & 15 \\
\hline 14 & Zidarski popravci žbuke, cementna glazura & 40 \\
\hline 15 & Troškovi skele & 30 \\
\hline
\end{tabular}

\subsubsection{Reaktivno održavanje}

Raspon troškova za reaktivno održavanje je nepredvidiv, budući da je gotovo nemoguće predvidjeti sve moguće kvarove. Broj tih aktivnosti je velik, jer predstavlja popravke i zamjene elemenata i materijala u sklopu intervencija kada dođe do kvarova i oštećenja.

U reaktivnom održavanju značajnije stavke su, na primjer, zamjena žarulja i fluo-cijevi, ostakljenje razbijenih prozora, popravci zaprljanih javljača vatrodojave, dijelova sanitarija, popravci prozora i vrata koje karakterizira učestalo korištenje radi namjene samog objekta. U planu 50-godišnjeg održavanja, za vrijednost reaktivnog održavanja korištena je srednja vrijednost stvarnih 10-godišnjih troškova za pojedine stavke. U tablici 4 prikazane su neke od aktivnosti reaktivnog održavanja.

\section{Tablica 4 - Prikaz ostvarenih aktivnosti reaktivnog održavanja korištenih za izradu plana održavanja fakultetske zgrade}

\begin{tabular}{|c|l|c|}
\hline redni broj & \multicolumn{1}{|c|}{ opis aktivnosti } & $\begin{array}{c}\text { vremenski interval } \\
\text { (godina) }\end{array}$ \\
\hline \hline 1 & Ostakljenje razbijenih staklenih površina & 1 \\
\hline 2 & Popravak vatrodojave & 1 \\
\hline 5 & Popravak krova, limarski radovi & 1 \\
\hline 6 & Popravak gromobranske instalacije & 1 \\
\hline 7 & Popravak klima uređaja/zamjena & 1 \\
\hline 8 & Popravak ili zamjena telefona i instalacije telekomunikacija & 1 \\
\hline 9 & Popravak poda parket, pločice, PVC, laminat & 1 \\
\hline 10 & Popravak toplotne podstanice, grijaćih tijela - radijatora & 1 \\
\hline 11 & Održavanje kanalizacije i vodovodne instalacije & 1 \\
\hline 12 & Održavanje elektro instalacija & 1 \\
\hline
\end{tabular}

\subsubsection{Troškovi uporabe građevine}

Troškovi uporabe građevine su posljednja skupina troškova u ukupnim troškovima gospodarenja građevine, ali i najznačajnija stavka u financijskom smislu. $U$ pogonske troškove ubrajamo troškove energenata - struja i toplinska energija, troškovi opskrbe pitkom vodom, odvoz komunalnog otpada i otpadnih voda, troškovi telefona i interneta, te troškovi održavanja higijene i okoliša (materijal za čišćenje, spremačice i domar). Najveća stavka u ovoj skupini su troškovi održavanja higijene zgrade, jer se ne smije dovesti u pitanje zdravstvena sigurnost studenata koji pohađaju fakultet. Grijanje je druga stavka po visini troškova, budući da se moraju poštovati standardi zagrijavanja radnih prostorija - predavaonica. 
Tablica 5 - Prikaz troškova uporabe građevine korištenih za izradu plana održavanja fakultetske zgrade

\begin{tabular}{|c|l|c|}
\hline \multirow{2}{*}{ redni broj } & \multicolumn{1}{|c|}{ opis aktivnosti } & $\begin{array}{c}\text { vremenski interval } \\
\text { (godina) }\end{array}$ \\
\hline \hline 1 & Opskrba pitkom vodom & 1 \\
\hline 2 & Opskrba električnom energijom & 1 \\
\hline 3 & Opskrba toplinskom energijom & 1 \\
\hline 4 & Telefonske i internetske usluge & 1 \\
\hline 5 & Odvoz komunalnog otpada & 1 \\
\hline 6 & Čišćnje zgrade i okoliša & 1 \\
\hline 7 & Komunalna naknada & 1 \\
\hline 8 & Naknada za slivne vode & 1 \\
\hline
\end{tabular}

\section{Analiza planiranih i ostvarenih troškova održavanja i uporabe za razdoblje od 1999. do 2008. godine}

U tablici 6 su prikazani prikupljeni podatci o ostvarenim troškovima održavanja i uporabe fakultetske zgrade za razdoblje od 1999. do 2008. godine, a prema definiranoj i opisanoj strukturi troškova održavanja i uporabe građevina prikazanoj u tablicama od 1 do 5 .

\section{Tablica 6 - Stvarni troškovi održavanja za razdoblje od 1999 do 2008 godine}

\begin{tabular}{|c|c|c|c|c|c|c|}
\hline GODINA & $\begin{array}{c}\text { Troškovi zakonom } \\
\text { propisanih periodičnih } \\
\text { pregleda }\end{array}$ & $\begin{array}{c}\text { Troškovi zamjene istrošenih } \\
\text { materijala i elemenata } \\
\text { građevine }\end{array}$ & $\begin{array}{c}\text { Troškovi periodičnih radova } \\
\text { i popravaka }\end{array}$ & $\begin{array}{l}\text { Reaktivno } \\
\text { održavanje }\end{array}$ & $\begin{array}{l}\text { Troškovi uporabe } \\
\text { građevine }\end{array}$ & $\begin{array}{l}\text { Ukupni troškovi održavanja po } \\
\text { godinama }\end{array}$ \\
\hline 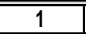 & 0,00 & 0,00 & $75.451,70$ & $1515.902,73$ & $182.979,99$ & $274.334,42$ \\
\hline 2 & 0,00 & $227.612,32$ & $45.822,48$ & $30.050,00$ & $199.881,91$ & $503.366,71$ \\
\hline 3 & $8.435,52$ & $388.100,70$ & $28.020,00$ & $43.605,55$ & $251.072,65$ & $719.234,42$ \\
\hline 4 & $8.384,20$ & $260.550,44$ & $17.607,49$ & $15.127,91$ & $325.792,62$ & $627.462,66$ \\
\hline 5 & $16.144,70$ & $93.104,05$ & $60.872,40$ & $14.181,86$ & $267.318,47$ & $451.621,48$ \\
\hline 6 & $21.520,70$ & $288.895,94$ & $96.764,32$ & $9.548,67$ & $348.965,13$ & $765.694,76$ \\
\hline 7 & $25.603,22$ & $168.336,83$ & $30.589,80$ & $5.775,85$ & $365.740,77$ & $596.046,47$ \\
\hline 8 & $23.832,52$ & $5.201,00$ & $7.590,36$ & $\begin{array}{l}11.067,54 \\
\end{array}$ & $417.395,73$ & $465.087,15$ \\
\hline 9 & $23.561,72$ & $9.170,00$ & $71.004,00$ & $6.254,15$ & $417.029,12$ & $527.018,99$ \\
\hline 10 & $24.114,04$ & 655,75 & $20.509,10$ & $13.605,30$ & $450.799,64$ & $509.683,83$ \\
\hline UKUPNO & $151.596,62$ & $1.441 .627,03$ & $454.231,65$ & $165.119,56$ & $3.226 .976,03$ & $5.439 .550,89 \mathrm{kn}$ \\
\hline
\end{tabular}

Ukupna vrijednost ostvarenih troškova aktivnosti održavanja i uporabe fakultetske zgrade iznosi $5.439 .550,89$ kuna. Na slici 3. prikazana je zastupljenost pojedine vrste troška u ukupnoj sumi. Najveći udio, $59 \%$, odnosi se na troškove korištenja građevine (pogonske troškove) i $27 \%$ na troškove zamjene istrošenih materijala i elemenata građevine. Ostali troškovi, koje čine troškovi reaktivnog održavanja, periodičnih popravaka i zakonom propisanih ispitivanja, pojedinačno su zastupljeni u manjoj mjeri (14\%). Kako bi usporedili stvarne i planirane troškove održavanja i uporabe, izrađen je plan održavanja za vremensko razdoblje od 2009. do 2059. godine s opisom aktivnosti koje su korištene u tablici 6 stvarnih troškova, za razdoblje održavanja od 10 godina. Izračunata je neto sadašnja vrijednost troškova održavanja i uporabe građevine za vremensko razdoblje od 50 godina, uz primjenu diskontne stope od 3,50\%. Neto sadašnja vrijednost troškova održavanja izračunata je prema izrazu [11]:

$$
N S V=\sum_{i=1}^{n} \frac{T O_{i}}{(1+r)^{i}}
$$

gdje je:

$\mathrm{TO}_{\mathrm{i}}$ - trošak održavanja u razdoblju i

$r$ - diskontna stopa

$\mathrm{n}$ - broj godina. 
Diskontna stopa, kao stopa diskontiranja, predstavlja mjeru vremenske vrijednosti novca, odnosno svodi buduće novčane iznose ili primitke na sadašnju vrijednost. Kod postupka diskontiranja na sadašnju vrijednost, diskontna stopa je izuzetno važnan element proračuna. Viša diskontna stopa ide u korist projektima s nižim kapitalnim troškovima, projektima kraćeg životnoga vijeka i projektima s visokim troškovima održavanja. Ovo pravilo vrijedi i obrnuto [12]. Pri izboru diskontne stope, veće diskontne stope pogoduju projektima s većim ukupnim životnim troškovima, odnosno projektima s dužim uporabnim vijekom. Izborom duljeg uporabnog vijeka i većih diskontnih stopa moguće je dobiti rezultate koji bi lako mogli dovesti do pogrešnih zaključaka, ako se ne analiziraju detaljno svi značajni faktori koji utječu na ukupne životne troškove građevina [8].

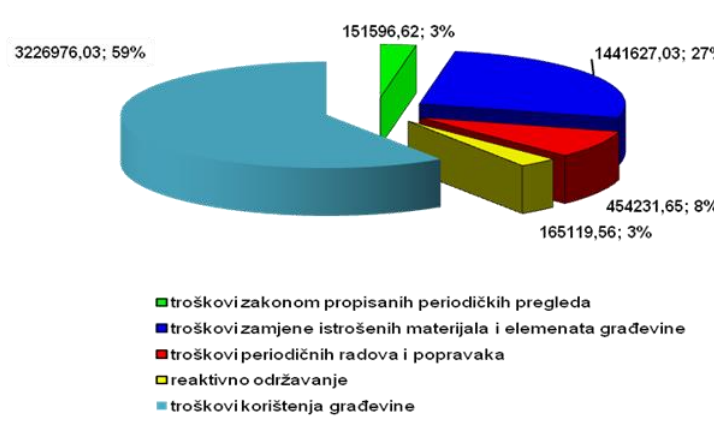

Slika 3 - Prikaz udjela pojedinih vrsta troškova u ukupnim troškovima održavanja i uporabe za razdoblje od 1999.do2008. godine

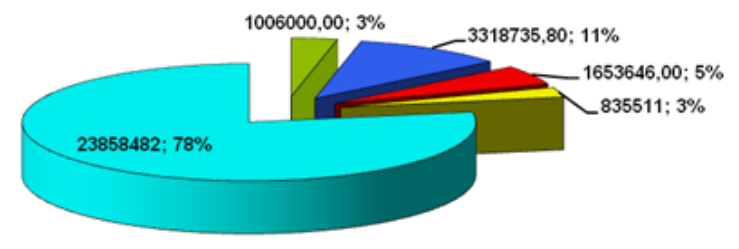

口troškovizakonom propisanih periodičkih pregleda 口troškovizamjene istrošenih materijala i elemenata građevine atroškoviperiodičnih radova i popravaka 口reaktivno održavanje

口troškovikoristenja arađevine

\section{Slika 4 - Prikaz udjela pojedinih vrsta troškova u ukupnim troškovima održavanja i uporabe}

Ukupna vrijednost planiranih troškova aktivnosti održavanja i uporabe fakultetske zgrade iznosi $30.672 .374,80$ kuna (NSV iznosi 14.171.898,10 kuna) za vremensko razdoblje od 50 godina. Najveći udio, 78\%, čine troškovi korištenja građevine (pogonski troškovi) i troškovi zamjene istrošenih materijala i elemenata građevine (11\%). Ostali troškovi, koje čine troškovi reaktivnog održavanja, periodičnih popravaka i zakonom propisanih ispitivanja, zastupljeni su u manjoj mjeri (11\%) [13].

$\mathrm{Na}$ slici 5 prikazani su ukupni ostvareni troškovi održavanja i ukupni troškovi održavanja, svedeni na neto sadašnju vrijednost u razdoblju od 1999. do 2008. godine [13].

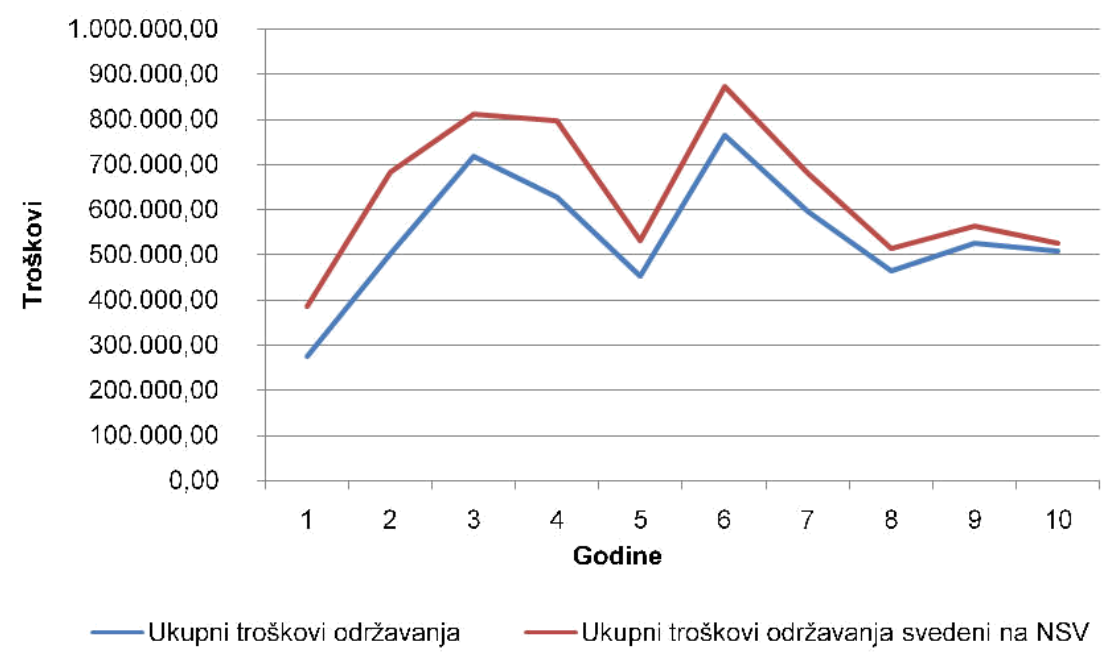

Slika 5 - Usporedni prikaz ukupnih ostvarenih troškova održavanja i ukupnih ostvarenih troškova održavanja svedenih na neto sadašnju vrijednost 
Na slici 6 prikazani su ukupni planirani troškovi održavanja i ukupni planirani troškovi održavanja fakultetske zgrade svedeni na neto sadašnju vrijednost za razdoblje od 2049. do 2059. godine [13].

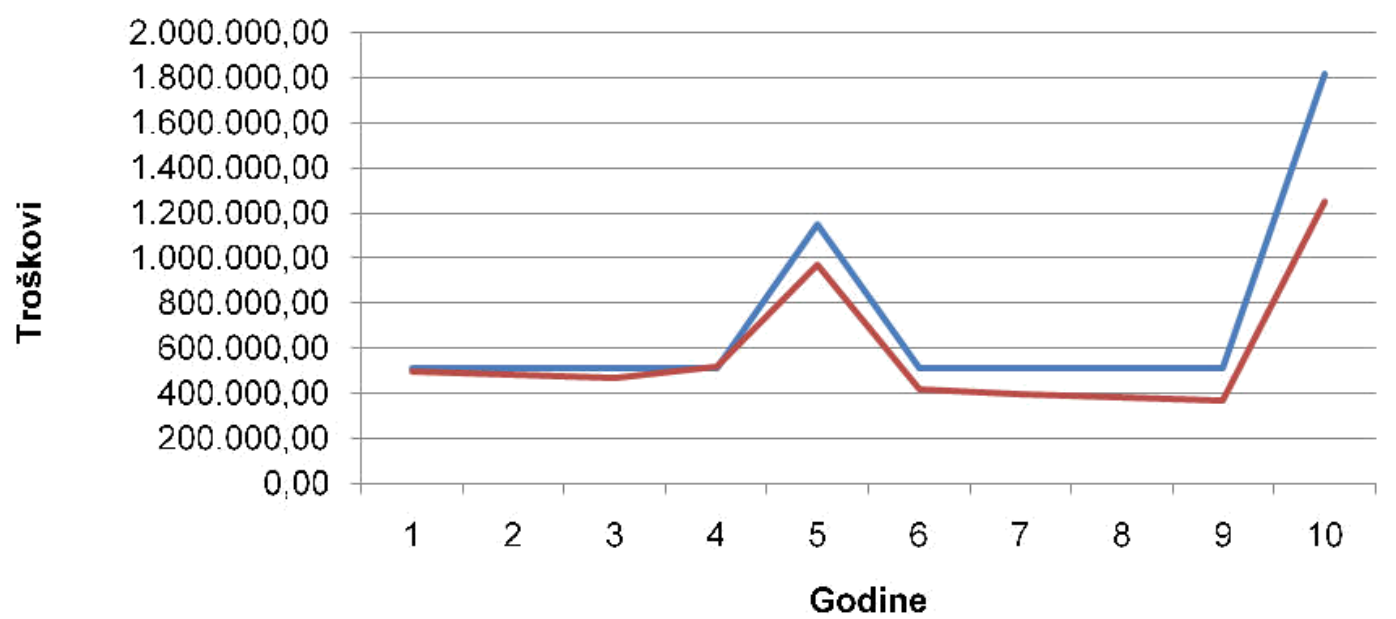

Ukupni troškovi održavanja U U Uupni troškovi održavanja svedeni na NSV

Slika 6 - Usporedni prikaz ukupnih ostvarenih troškova održavanja i ukupnih ostvarenih troškova održavanja svedenih na neto sadašnju vrijednost

Na slici 7 prikazani su stvarni troškovi održavanja fakultetske zgrade u razdoblju od 1999. godine do 2008. godine. U tom razdoblju zgrada je bila stara 40 , odnosno 50 godina. Podatci su uspoređeni s planiranim troškovima za naredno razdoblje od 50 godina (zadnjih 10 godina uporabe zgrade). Iz usporednog dijagrama je vidljivo da troškovi održavanja zgrade, kada se približi vijeku trajanja od 100 godina, značajno rastu radi potrebne zamjene većine ugrađenih materijala i elemenata. Može se zaključiti da daljnje ulaganje u obnovu zgrade nije isplativo [13].

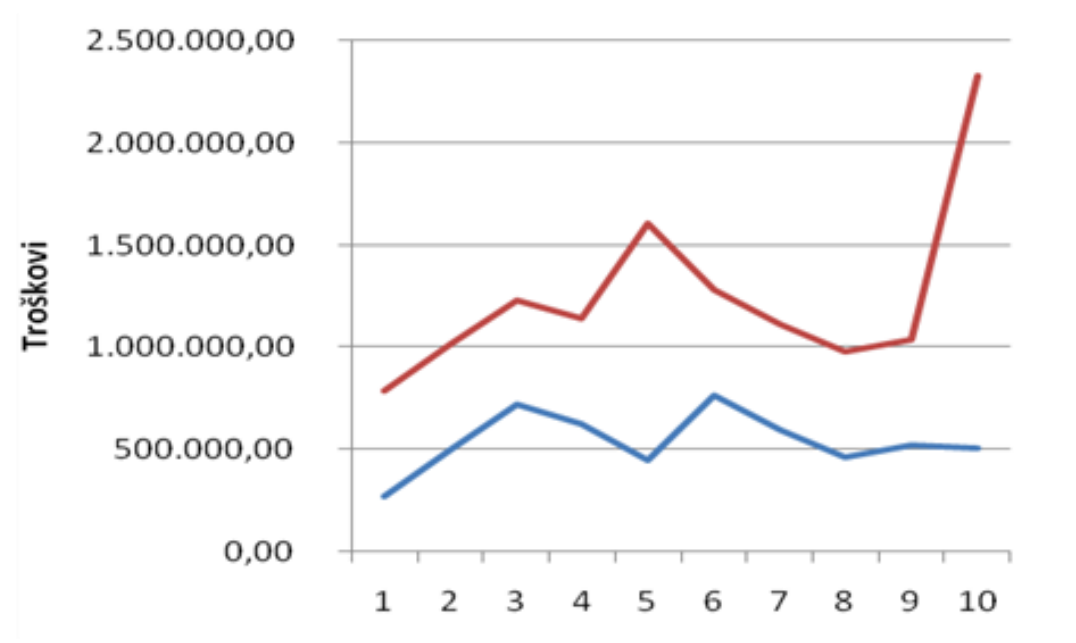

\footnotetext{
- Planirani ukupni troškovi održavanja zgrade za period od 2049. do 2059. godine (zadnjh 10 godina uporabe zgrade)

Ostvareni ukupni troškovi održavanja zgrade za period od 1999. do 2008. godine
}

Slika 7 - Usporedni prikaz planiranih (od 2009. do 2059. godine) i ostvarenih troškova za zadnjih 10 godina uporabe zgrade (od 1999. do 2008. godine) 
Kako bi se mogli usporediti planirani troškovi održavanja i uporabe za 50-godišnje razdoblje od 2009. do 2059. godine, predviđeni su i troškovi izvedbe izgradnje zgrade prema etalonskoj cijeni građenja za analiziranu zgradu. Predviđeni troškovi izvedbe nove građevine izračunati su na temelju podatka o etalonskoj cijeni građenja koji godišnje donosi i objavljuje Ministarstvo zaštite okoliša, prostornog uređenja i graditeljstva [14]. Vrijednost etalonske cijene građenja vezana je uz euro i iznosi 792,41 EUR po $\mathrm{m}^{2}$ korisne površine zgrade.

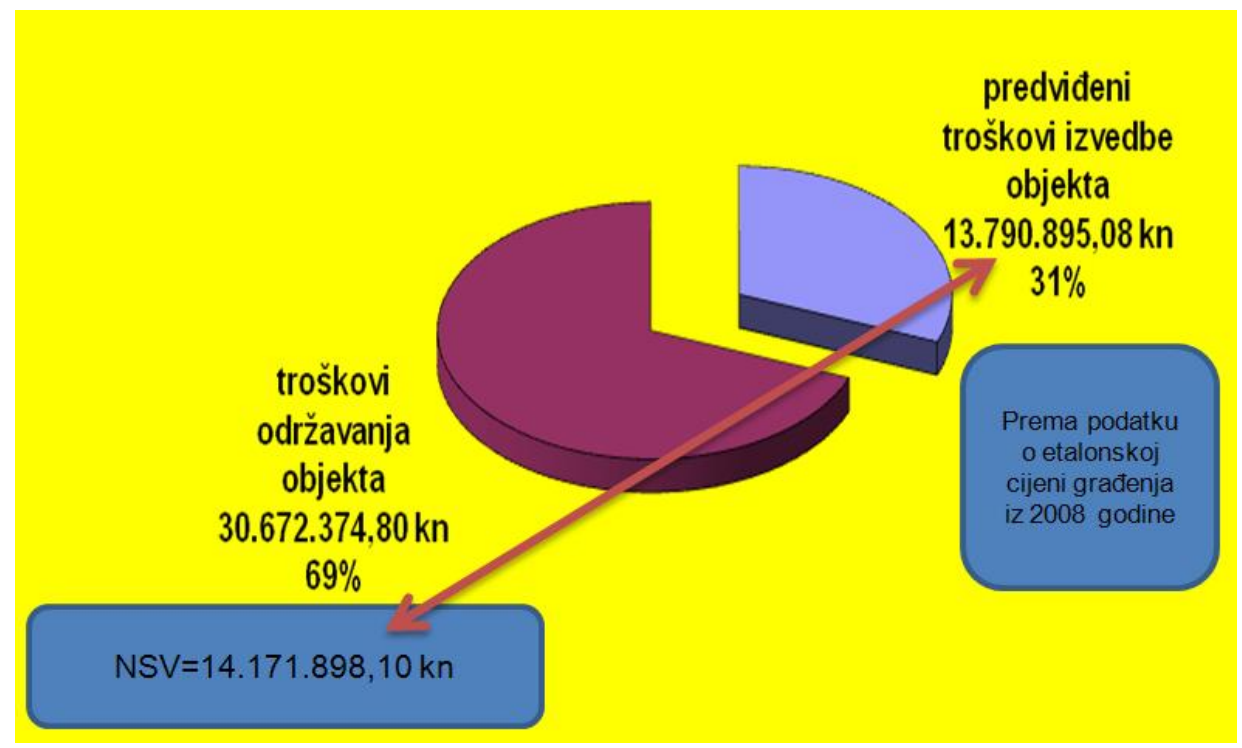

\section{Slika 8 - Prikaz odnosa troškova izgradnje zgrade i održavanja zgrade za predviđeno razdoblje od 50 godina}

Iz usporedbe na slici 8 može se zaključiti da troškovi održavanja zgrade od $2.374,67 \mathrm{~m}^{2}$ iznose $69 \%$, dok bi izgradnja zgrade iste kvadrature iznosila 31\% troškova. Budući da fakultetska zgrada 2059. godine navršava 100 godina trajanja, daljnja ulaganja bi bila neisplativa. U slučajevima kada cijena zemljišta premaši trenutačnu vrijednost građevine, ekonomski je opravdano uklanjanje stare građevine i prenamjena zemljišta, najčešće za izgradnju nove građevine čija vrijednost u pravilu višestruko nadmašuje vrijednost uklonjene građevine [15].

\section{Zaključak}

Planiranje održavanja i uporabe građevina postaje sve važnije u vrijeme nastojanja smanjenja troškova vlasništva nad izgrađenim građevinama. Potrebno je analizirati i napraviti plan održavanja i uporabe prije izgradnje, budući da je u toj fazi najveći utjecaj na troškove građenja te održavanja i uporabe građevine. Realnost toga plana treba provjeriti prije početka uporabe, budući da se javljaju česte izmjene projekta u fazi realizacije. Čak i ako je eksploatacija građevine već duže vrijeme u tijeku, a plana održavanja i uporabe nema, treba ga izraditi za preostalo razdoblje predviđeno za uporabu građevine te se na taj način može pozitivno utjecati na dinamiku i ukupan iznos troškova eksploatacije, naročito ako se planira rekonstrukcija, dogradnja, promjena namjene, poboljšanje namjene zgrade i slično.

U ovom radu prezentirana je usporedna analiza stvarnih i planiranih troškova desetogodišnjeg održavanja i uporabe građevine namijenjene fakultetskoj funkciji. Definirane su aktivnosti planiranog preventivnog održavanja, reaktivnog održavanja i zamjene istrošenih materijala, te troškovi uporabe na osnovi kojih se uspoređuju isti troškovi za razdoblja od 10 i 50 godina.

Ako zanemarimo troškove uporabe zgrade analiziranog fakulteta koji čine veliki dio troškova (59\%), najveći udio troškova koji se odnosi na zakonom propisane troškove, troškove periodičnih radova i popravaka te reaktivne troškove, jesu troškovi zamjene istrošenih materijala (27\%). To je posljedica činjenice kako je postojeća građevina u promatranom razdoblju bila u petom desetljeću uporabe (zgrada je izgrađena 1959. godine) te je za većinu ugrađenih materijala prošao planirani vijek trajanja. 
U obrađenome planiranom razdoblju od 2009. do 2059. godine najveće povećanje troškova uočava se u posljednjih 10 godina planirane uporabe (kada zgrada navršava 100 godina), budući da u tom razdoblju većini materijala i elemenata konstrukcije koji su već jednom i izmijenjeni, ističe uporabni vijek.

Planirani troškovi održavanja zgrade u razdoblju od 2009. godine do 2059. godine iznose približno $69 \%$, dok su troškovi izvedbe objekta oko $31 \%$.

Iz analiza provedenih u ovome radu vidljiva je važnost planiranja održavanja i uporabe građevina, budući da omogućuje racionalnije gospodarenje postojećim građevinama, kao i racionalniji pristup projektiranju novih građevina uz mogućnost smanjenja troškova vlasništva u uporabnom vijeku građevina, odnosno potreba za sustavnim predviđanjem i trošenjem sredstava za održavanje i uporabu građevina.

\section{Literatura}

[1] Aničić, D., Planiranje uporabnog vijeka građevine - prijevod norma niza ISO 15686, Građevinski godišnjak 03/04. 2004, HDGI.

[2] Marenjak, S., Održavanje zgrada - skripta, 2008.

[3] Hrvatski sabor, Zakon o prostornom uređenju i gradnji, 2007.

[4] Marenjak, S.; El-Haram, M.A.; Horner, R.M.W.: Procjena ukupnih troškova u visokogradnji, Građevinar, 2002, 54 .

[5] Hrvatski sabor, Uredba o načinu utvrdivanju cijene stana i garaže, 1992.

[6] Cerić, A.; Katavić, M.: Upravljanje održavanjem zgrada, Građevinar, 2000., 53.

[7] Nunen, H.v., Hendriks, N.A.; Erkelens, P.A.: Service life as main aspect in environmental assessment, 2004, Available from: http://alexandria.tue.nl/openaccess/Metis211340.pdf

[8] Marenjak, S., Krstić, H.: Sensitivity analysis of Facilities Life Cycle Costs, Tehnički Vjesnik, 2010. 17(4).

[9] Sterner, E., 'Green procurement' of buildings: a study of Swedish clients considerations, Construction Management and Economics, 2002. 20.

[10] DZNM, Zgrade i druge građevine - Planiranje vijeka uporabe - 1. dio: Opća načela (ISO 15686-1:2000). 2002, Zagreb, Državni zavod za normizaciju i mjeriteljstvo.

[11] Medanić, B., Pšunder, I., Skendrović, V.: Neki aspekti financiranja i financijskog odlučivanja u građevinarstvu. 2005, Osijek, Sveučilište J. J. Strossmayera u Osijeku, Građevinski fakultet Osijek, Osijek.

[12] Woodward, D.G.: Life cycle costing-theory, information acquisition and application, Internattonal Journal of Project Management, 1997., 15.

[13] Bognar, B., Održavanje zgrade Fakulteta (Diplomski rad). 2009., Sveučilište J. J. Strossmayera u Osijeku, Građevinski fakultet Osijek.

[14] Hrvatski sabor, Podatak o etalonskoj cijeni građenja (NN 67/09), 2009.

[15] Marić, Ž.: Svjetski trendovi u rušenju građevina i recikliranju građevinskog otpada, Sabor hrvatskih graditelja, Cavtat, 2004. 